\title{
Efforts of State-Owned Enterprises (SOE) in Disseminating Pancasila by Actualizing Tri Hita Karana (THK)
}

\author{
I Gusti Ngurah Santika ${ }^{1)}$, I Nengah Suastika ${ }^{2)}$ \\ 1) Elementary School Teacher Education Study Programme, Faculty of Teacher Training and \\ Education Universitas Dwijendra, Jl. Kamboja No.17, Denpasar, Indonesia 80113 \\ ${ }^{2)}$ Elementary Education, Postgraduate, Universitas Pendidikan Ganesha, Jl. Udayana No. 11, Indonesia \\ 81116 \\ Corresponding Author: I Gusti Ngurah Santika Email: ngurahsantika88@gmail.com
}

History: Received 04/12/2021 $\mid$ Revised 12/12/2021 $\mid$ Accepted 26/12/2021 | Published 31/01/2022

\begin{abstract}
This research aims to determine the efforts of SOE in disseminating Pancasila by actualizing Tri Hita Karana. This type of research is descriptive qualitative. Data was collected by means of documentation. The results of this research indicated that the dissemination of Pancasila by SOE through the actualization of Tri Hita Karana can be seen from the ESR and CSR. The harmonious relationship between SOE and God is carried out through SOE activities that are oriented towards supporting the community in religion, for example building houses of worship, Ramadan package support, Iftar with Orphans, Hajj support, Tirtayatra, Pilgrimage, and religious discussions, as well as spiritual development. The dissemination of Pancasila through the actualization of Tri Hita Karana, especially in establishing a harmonious relationship with the environment is carried out by SOE through investment in the environmentally friendly sector, maintaining a balance in the exploitation of natural resources, and waste treatment (waste recycling). The dissemination of Pancasila through the actualization of Tri Hita Karana by SOE in building harmonious relations with humans is reflected in their concern for the community by empowering them socially and economically, education/training, improving health, organizing public facilities and infrastructure.
\end{abstract}

Keywords: Pancasila; State Owned Enterprises; Tri Hita Karana

\begin{abstract}
Abstrak. Penelitian ini bertujuan untuk mengetahui upaya BUMN dalam mendiseminasikan Pancasila dengan mengaktualisasikan Tri Hita Karana. Jenis penelitian ini adalah deskriptif kualitatif. Pengumpulan data dilakukan dengan studi dokumentasi. Hasil penelitian ini menunjukan diseminasi Pancasila oleh BUMN melalui aktualisasi Tri Hita Karana dapat dilihat dari TJSL dan CSRnya. Hubungan harmonis antara BUMN dengan Tuhan dilakukan melalui kegiatan BUMN yang orientasinya mendukung masyarakat dalam keagamaan, misalnya membangun rumah ibadah, bantuan paket Ramadhan, Buka Puasa Bersama Anak Yatim, bantuan naik haji, Tirtayatra, Ziarah, dan diskusi keagamaan, serta pembinaan rohani. Diseminasi Pancasila melalui aktualisasi Tri Hita Karana, terutama dalam menjalin hubungan harmonis dengan lingkungan dilakukan BUMN melalui investasi pada sektor ramah lingkungan, menjaga keseimbangan eksploitasi sumber daya alam, pengolahan limbah (daur ulang limbah). Diseminasi Pancasila melalui aktualisasi Tri Hita Karana oleh BUMN dalam membangun hubungan harmonis dengan manusia tercermin dari kepeduliannya kepada masyarakat dengan memberdayakan secara sosial dan ekonominya, pendidikan/pelatihan, peningkatan kesehatan, penyelenggaraan sarana, dan prasarana umum.
\end{abstract}

Kata kunci: Pancasila; BUMN; Tri Hita Karana 


\section{INTRODUCTION}

It has been more than seven decades that Pancasila has stood firmly and firmly as the ideology of the Indonesian nation (Santika et al., 2018). However, until now the dissemination is more directed at public discourse than real action (Sutrisno et al., 2019). In its journey, the dissemination of Pancasila continues to be a hot discussion in all social levels of Indonesian society (Santika, 2020c). Although various strategies have been implemented by the state, especially the government, it must be acknowledged that it is not easy to disseminate Pancasila in the life of society, nation and state (Santika et al., 2019). Therefore, we need the right method supported by the involvement of all parties in disseminating Pancasila. Here the Government as a state administrator is obliged to show his example in an effort to disseminate Pancasila (Santika, Sujana, et al., 2019). Considering that the Government has legal access and power to enter and organize all sectors of the nation's life, Indonesia's national economy is no exception (Kusumadewi, 2013). StateOwned Enterprises (SOE) as one of the actors in economic activities in the Indonesian national economy based on the principles of economic democracy can be used by the Government as a role model in disseminating Pancasila.

However, it must be understood together that it is not easy for SOE to disseminate Pancasila in their business activities. For this reason, SOE need a holistic and comprehensive strategy in their efforts to disseminate Pancasila (Santika et al., 2021). SOE needs to involve various relevant aspects of life in order to be successful in disseminating Pancasila. As a country whose society is religious-spiritual, the concept of religion and the business wheel of SOE must go hand in hand and be integrated simultaneously to facilitate the dissemination of Pancasila. The concept of religion, which according to the perspective of western countries must be separated from the state, is unacceptable in Indonesia (Santika, 2021b). Religious principles that have been proven to lead people to peace should be embraced and empowered by the state, especially SOE. By actualizing religious principles in their economic system optimally, it will make it easier for SOE to disseminate Pancasila. This is in line with the recognition of Pancasila regarding the symbiotic relationship of mutualism between religion and the state is not separated (Kartika, 2015). In fact, it is religious principles that should be a strong grip and guide for the implementation of the state economy, especially SOE so that the dissemination of Pancasila can run in accordance with the expectations of the Indonesian people (Santika, 2021a). Regarding the dissemination of Pancasila through religion, the actualization of the Tri Hita Karana (THK) principle by SOE is the solution offered in this research. 
Tri Hita Karana itself is a Hindu cosmology which is a universal and strong philosophy of life in achieving the happiness of its people. Likewise, Pancasila as an ideology always offers true happiness to the Indonesian people through the way of peace (Sila et al., 2020). How strategic is the position of Pancasila in the life of the nation and state, then Tri Hita Karana in the concept of Hinduism also has a clear orientation/ideal in guiding or guiding and directing mankind to establish a harmonious relationship between man and God, man and nature, and man and man (Purana, 2016). This means that if Tri Hita Karana is consistently actualized by SOE, of course, it will indirectly show the seriousness of the Government in efforts to disseminate Pancasila through the country's economic system. In relation to the dissemination of Pancasila, the actualization of Tri Hita Karana by SOE is very interesting to study comprehensively. Considering the Tri Hita Karana principle in the concept of Hinduism which places and positions "humans" as a point of view or central point in establishing harmonious relationships with God, nature, and humans, then they move and shift into business entities, namely SOE (Rini, Wulan Setyo., Salim, M Agus., \& Priyono, 2021).

This narrative, in turn, raises an applicable question, namely how can SOE be able to disseminate Pancasila by actualizing the Tri Hita Karana principle in conducting its business? Given that in Hinduism, Tri Hita Karana itself positions and places humans as the main actors in creating/realizing happiness in the world (Rai \& Suarningsih, 2019). Meanwhile, SOE is a state-owned enterprise which is clearly different from humans. By looking at these basic differences, it is necessary to explore further whether SOE can actualize the Tri Hita Karana principle in an effort to disseminate Pancasila. Considering that THK as a universal Hindu consept has not been fully involved in effort to disseminate Pancasila. Therefore, the title adopted in this study is the Efforts of State-Owned Enterprises (SOE) in Disseminating Pancasila by Actualizing the Principles of Tri Hita Karana (THK).

\section{RESEARCH METHODS}

The research method used in this research is descriptive qualitative. Qualitative descriptive research seeks to describe a social phenomenon that is focused on solving problems in the present and future (Santika, 2020a). Qualitative research style seeks to construct reality and understand its meaning. Qualitative descriptive research is aimed at describing and describing existing phenomena, both natural and human engineered, which pays more attention to the characteristics, quality, interrelationships between activities.

The social phenomenon or phenomenon seen in this study is that the state, 
especially the government, has not been able to optimally disseminate Pancasila in the life of the nation and state. The government should disseminate Pancasila in all aspects of life, including the country's economic sector. Theoretically, data collection techniques in qualitative research consist of four types, namely observation, interviews, documentation, and combination or triangulation (Sugiyono, 2015). In this study, the data collection method used was the study of documentation and literature. Literature study is carried out by looking for various written sources, both in the form of books, archives, magazines, articles, and journals, as well as documents that can assist researchers in clearly revealing the efforts of SOE in disseminating Pancasila by actualizing the $T r i$ Hita Karana principle. To strengthen this literature study, the books and scientific journals used were selected for publication in the last ten years (Aryawan, 2021).

\section{DISCUSSION}

As a state of law (rule of law), the efforts of SOE in disseminating Pancasila by actualizing Tri Hita Karana can be understood holistically if we observe and analyze the various laws and regulations governing their obligations (Santika, 2019). Juridically, Law Number 40 of 2007 and Government Regulation Number 47 of 2012 has regulated the imperative responsibility of SOE in the perspective of Tri Hita Karana as another form of Pancasila dissemination. Therefore, it can be stated that SOE which is a business entity with state ownership shares above $50 \%$ in moving the wheels of its business has disseminated Pancasila by actualizing the Tri Hita Karana as stated in the form of its obligations and responsibilities. The dissemination of Pancasila carried out by SOE through practice can be seen from the main principles it carries, namely Environmental Social Responsibility (ESR) and Corporate Social Responsibility (CSR) (Kapuy et al., 2018).

In its journey, ESR and CSR as another form of Pancasila dissemination have become an inseparable part of legal obligations that must be carried out by SOE. However, before reaching a lengthy discussion regarding the efforts of SOE in disseminating Pancasila by actualizing Tri Hita Karana through ESR and CSR, it is necessary to discuss these two concepts in order to gain a more comprehensive and holistic understanding. The discussion will be carried out later, but before that it will be discussed further in the legal basis. ESR according to Article 1 Number (3) of Law no. 40 of 2007 concerning Limited Liability Companies (UUPT), states that: "Social and Environmental Responsibility is the Company's commitment to participate in sustainable economic development in order to improve the quality of life and the environment that is beneficial, both 
for the Company itself, the local community, and the community at large. generally."

The concretization of SOE's efforts in disseminating Pancasila through the actualization of Tri Hita Karana can be fully understood by looking at the Elucidation of Article 74 of the Company Law which outlines the objectives of ESR. In the explanation, it is clearly explained that the purpose of ESR is to continue to create a harmonious, balanced and appropriate corporate relationship with the environment, values, norms and culture of the local community. If we look closely at the objectives of ESR, SOE implicitly have an obligation to disseminate Pancasila through the actualization of Tri Hita Karana by building or creating harmonious and balanced (harmonious) relationships . The harmonious relationship built by SOE through the actualization of Tri Hita Karana is complex, both with values, the environment, and the local community. Thus, ESR can be used as a powerful tool for SOE in disseminating Pancasila by adhering to the actualization of Tri Hita Karana.

Not only ESR, other forms of SOE's efforts in disseminating Pancasila through the actualization of Tri Hita Karana can also be carried out with CSR programs. CSR is an idea about the importance of corporate responsibility and concern (SOE) which is realized through programs that have social values and take sides with the community and the environment. CSR is a form of corporate responsibility to the surrounding environment. CSR is the commitment of the company or the business world to contribute to sustainable economic development by paying attention to corporate social responsibility and emphasizing the balance between attention to economic, social and environmental aspects (Swarniti, 2021a)".

To better understand the concrete form of SOE's efforts in disseminating Pancasila through the actualization of the Tri Hita Karana principle, it is necessary to reexplain in detail along with examples. With the actualization of the actualization of Tri Hita Karana by SOE through their business practices or operations, it can be said that Pancasila as the ideology and way of life of the nation has actually been disseminated in the life of the state, especially the economic system (Santika, 2020b). How SOE's efforts in disseminating Pancasila through the actualization of Tri Hita Karana can be observed in terms of establishing or building a harmonious relationship between companies and God Almighty, companies and the environment or nature, and companies and humans (Swarniti, 2021b). If the three concepts of harmony have been able to be implemented by SOE well, it means that the actualization of Tri Hita Karana in the context of disseminating Pancasila has been achieved.

Harmonious relationship between SOE and God Almighty. In general, the Tri Hita Karana principle in the concept of 
Hinduism is widely known as a human effort to always maintain harmony, balance, and harmonious relationships in the universe (Rita, 2019). This means that Tri Hita Karana is actually positioning humans through their behavior as a means of application to create peace in the world (Saputra et al., 2018). However, in the context of this research, harmonious relationships are not only capable of being constructed by humans. Because SOE as a state company can actually create, realize, and implement Tri Hita Karana in relation to building and realizing a harmonious relationship with God Almighty. Considering the company in this case SOE consists of a collection of people who are tasked with operating it. Humans are the ones who drive or run SOE to achieve its goals. Meanwhile, humans themselves are religious beings (homo religious) who fear God Almighty (Ahsanulkhaq, 2019).

The operation of the SOE business carried out by humans certainly opens a wide way for companies to establish a harmonious relationship with God Almighty. Through various human activities that are contained in SOE policies or decisions, especially those that are in direct contact with religious aspects, it can actually be said that the dissemination of Pancasila through the actualization of Tri Hita Karana has been carried out in the field. Considering that SOE's dissemination of Pancasila by applying Tri Hita Karana can only be seen and known from its various actions which ultimately lead to the creation of a harmonious relationship between the company and God Almighty. Although the concepts offered need to be re-explained in detail with contextual examples to make it easier for readers to understand the purpose and intent of this research.

To find out more about SOE's efforts in disseminating Pancasila through the actualization of Tri Hita Karana, especially to build harmonious relations, it can be observed from the CSR principles that have been implemented. SOE's efforts in establishing a harmonious relationship with God Almighty can be understood from various socioreligious activities whose direction and orientation is to support the community in worship (Santika, I. G. N. et al., 2019). SOE in Indonesia has essentially tried to actualize the Tri Hita Karana principle through the operation of its business. For example, SOE Consultant Karya provided financial assistance to repair the worship facilities and infrastructure of the Nurul Huda Mosque located in Pabuaran Village, Gobang Village, Bogor Regency, West Java. This assistance activity is carried out in order to support the Sustainable Development Goals (SDGS) program. 

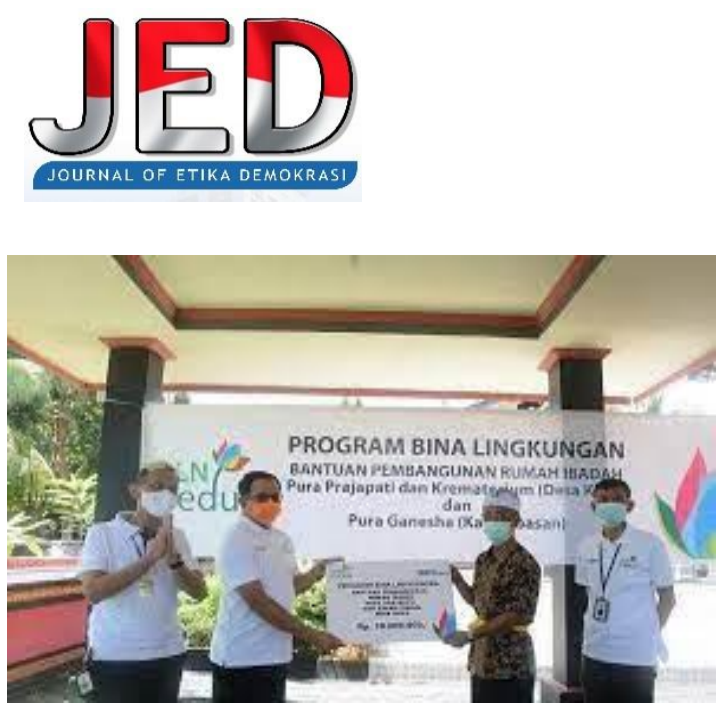

Figure 1 SOE's efforts in building a harmonious relationship with God.

In addition to the CSR program, SOE's efforts to establish a harmonious relationship with God Almighty are also realized through the company's CSR program. For example, PT Pertamina (Persero) as SOE which is engaged in the energy sector (Gumilar et al., 2019) in disseminating Pancasila through the actualization of Tri Hita Karana related to efforts to build a harmonious relationship with the Creator, it can be observed from the realization of CSR which is in contact with religious affairs. In general, this CSR is manifested in the form of operational assistance for the construction of houses of worship, Ramadan Package assistance, Eid alQurban assistance, and Iftar with Orphans. SOE's efforts in disseminating Pancasila by SOE by actualizing Tri Hita Karana are intended to always direct companies, especially employees or employees to always be grateful to God Almighty for what they already have. (Santika, 2018).

That way, SOE employees have more faith and fear of God Almighty and always stay away from actions that are contrary to or
ISSN: p-2540-8763 / e-2615-4374

DOI: $10.26618 /$ jed.v\%vi\%i.6488

Vol: 7 Number 1, January 2022

Page: 14-27

contrary to religious teachings, such as corruption. The statement is in accordance with the research results (Lestari, 2021), that religion has an effect as a motivation in encouraging humans to carry out an activity, because actions carried out with the background of religious beliefs are considered to have elements of purity and obedience. The motivation that arises has a positive effect on individual behavior.

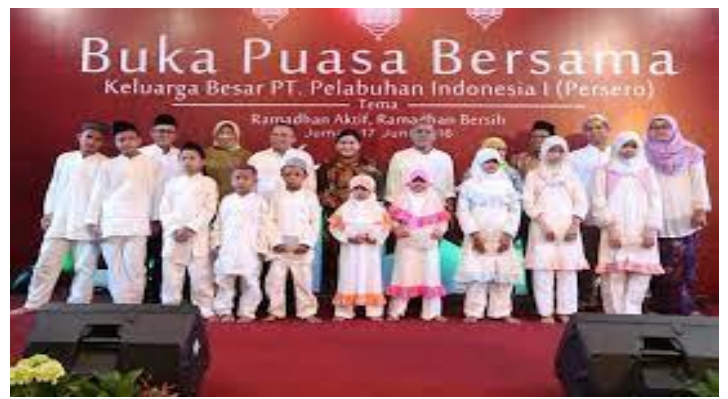

Figure 2 Iftar with the extended family of PT Pelabuhan Indonesia I (Persero).

It should be understood that the effort to establish a harmonious relationship with God Almighty as the actualization of Tri Hita Karana is not only manifested by stating SOE in the form of physical development (holy places), but is carried out through the development of the personality of its employees so that in the future they are more devoted to God Almighty. . It is known that SOE has spiritual guidance, such as spiritual guidance PT Telkom, spiritual guidance PT Bank, and spiritual guidance PT Indosat. The main focus or target of SOE is why it is necessary to provide spiritual guidance to its employees so that when they work or carry out their duties they always pray to be able to 
provide the best benefit for the benefit of their lives, including for the good of others. (Santika, 2017).

As mentioned above, that in an effort to develop the personality or character of all SOE employees, for example among Muslims, so that there is an application of noble character as a new value to spur and improve performance in every SOE company, the SOE Ministry invites the active role of the Nahdlatul Ulama Executive Board (PBNU). Ulama from the Nahdliyin will be involved in giving lectures and studies at various mosques located in all SOE offices (SOE, 2020). With the various religious activities carried out by SOE, in essence, the dissemination of Pancasila has been carried out in accordance with the Tri Hita Karana principle, especially in establishing a harmonious relationship with God Almighty. Here employees as an integral part of SOE are invited to get closer to a good relationship with the Creator. A harmonious relationship between employees and God Almighty will indirectly have good implications for SOE.

As for other religious activities carried out by SOE to establish a harmonious relationship with God Almighty, namely holding religious studies or discussions, such as monthly discussions on Hinduism by inviting outside speakers; holding Dharma Santi Nyepi and Galungan; provide assistance to the Pinanditha, as was done by spiritual guidance PT Indonesia. spiritual guidance PT
Telkom annually sends its Hindu employees to do Tritayatra to India. This is in line with Hajj assistance for Muslim employees and the Pilgrimage to Jerusalem for Christians. This program proves that SOE strives to build a harmonious relationship with God Almighty through mental and spiritual improvement of its employees. Employees are the ones who act as a bridge between SOE and God Almighty.

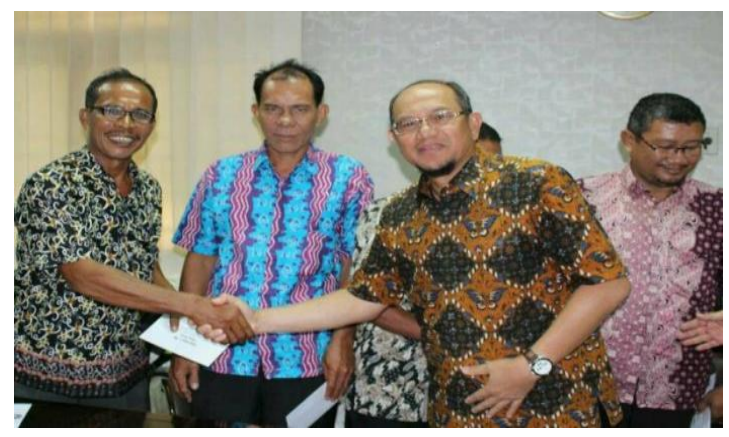

Figure 3 PTPN III Departs Six Employees for Spiritual Pilgrimage to Jerusalem

Harmonious relationship between SOE and the environment or nature.

Regarding SOE's efforts in disseminating Pancasila through the actualization of Tri Hita Karana, especially in terms of building a harmonious relationship with nature or the environment, it must start with the history of the birth of CSR. By conveying the origins of the birth of CSR, at least it can provide comprehensive insight and understanding related to SOE's efforts to build a harmonious relationship with the environment. The emergence of the concept of CSR is motivated by the exploitation of natural resources and the destruction of the environment, because the operations of companies or industries that are competing to 
make as much profit as possible seem to ignore the social impacts that can occur, resulting in an environmental crisis. (Swarniti, 2021c).

CSR itself was born from community pressure on the behavior of companies that ignore social responsibilities such as environmental destruction and exploitation of natural resources (Harahap, 2010). Since then, there has been a high awareness that companies are no longer faced with responsibilities that are based on and based on a single bottom line, namely corporate values which are not only reflected in financial conditions, but corporate responsibility must be oriented to the triple bottom line whose concept was developed by Lekington, namely paying attention to "3P", namely profit (sustainable profit/profit), paying attention and being involved in fulfilling the welfare of the community around the company (people), and participating and contributing actively in preserving the environment (planet) (Swarniti, 2019).

In an effort to disseminate Pancasila through the actualization of the principles of Tri Hita Karana, especially to build a harmonious relationship with the environment, SOE has carried out investments in environmentally friendly sectors, maintaining a balance in the exploitation of natural resources, processing waste (waste recycling), increasing social expenditures. (social costs) as well as other ways to maintain environmental balance and the like (Memed,
2001). Corporate CSR, including SOE, is regulated in Article 44 of Law Number 40 of 2007, which explicitly states that "Companies that carry out their business activities in the field of and/or related to natural resources are obliged to carry out social and environmental responsibilities. In the concept of CSR and SOE CSR related to the actualization of Tri Hita Karana as a form of Pancasila dissemination, it has a fundamental role for all parties.

Disclosure of social responsibility or often called CSR is the process of communicating the environmental effects of a company's economic actions on certain groups in society and on society as a whole. (Ardian, 2013). The dissemination of Pancasila by SOE through the actualization of Tri Hita Karana in protecting the environment or nature, has been determined by the state by requiring each company to set aside $1-3 \%$ of profits for CSR implementation. The company has a responsibility to protect the environment and protect it from the adverse effects of its business operations. The objective of the CSR program in the environmental sector is to support community empowerment that is sustainable and environmentally sound in maintaining the balance of nature for future generations (Rakhmawati, 2011).

The dissemination of Pancasila by SOE through actual actualization of the Tri Hita Karana principles in relation to building a harmonious relationship with the 
environment has actually been carried out, for example PT Len Industri. In order to improve the company's environmental management performance and to prevent environmental pollution into community areas, PT Len Industri has a strong commitment to maintaining environmental management, both direct and indirect impacts on environmental activities. Not only PT Len Industri, other SOEs that have disseminated Pancasila through the actualization of Tri Hita Karana, for example, are PT Pertamina (Persero). The direction of PT Pertamina's CSR focuses on five major programs, namely Pertamina and education, Pertamina and the community, Pertamina and health, and Pertamina and the environment.

As a state company engaged in the national energy sector, PT Pertamina is always committed to prioritizing the balance and preservation of nature, the environment and society. In accordance with the objectives of CSR, that by prospering humans, nature and the environment, PT Pertamina's subsidiary is able to achieve sustainable business growth. Moreover, now PT Pertamina has decided and determined one of the strategic initiatives as a form of its commitment, namely environmental conservation. In this case, PT Pertamina wants to focus on the implementation of CSR in order to support the achievement of the Company Performance Rating Program (PROPER) by prioritizing environmental conservation, both nature and society according to the requirements set by the PROPER Council (Ministry of Environment and Forestry Indonesia).

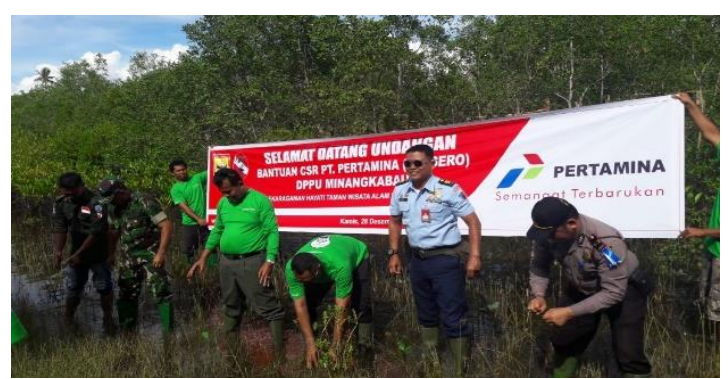

Figure 4 Pertamina Preserves Mangrove Planting Environment in West Sumatra

Harmonious relationship between SOE and human.

In the concept of Tri Hita Karana, especially regarding building a harmonious relationship between SOE and humans, it can be observed from their social responsibilities. SOE's social responsibility as a form of CSR implementation is a managerial tool used by companies to establish peace and avoid social conflicts, especially with the surrounding community. Social and environmental responsibility is not merely a matter of morals or corporate kindness, but what is more prominent is the factor of the company's interests, both internal interests, namely economic interests, as well as external interests in the form of image improvement and efforts to secure the company's operations from various threats. kinds of pressure or demands, both from the authorities and from the community itself (Rauf, 2016).

In SOE companies, the CSR program is realized in the form of the Partnership and Community Development Program (PKBL) in 
accordance with Decree No. 236/MBU/2003.

PKBL is the obligation of state-owned companies in the form of social responsibility to the surrounding community for the social, religious and economic fields of the community. In relation to the actualization of Tri Hita Karana as a form of Pancasila dissemination, SOE's CSR functions and acts as a powerful tool to solve various company problems, namely adaptation problems to the external environment and internal integration.

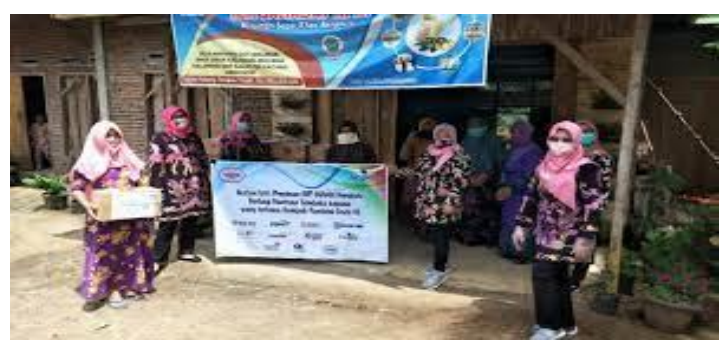

Figure 5 Social Assistance IIP SOE Bengkulu as a Form of Social Care

The basic concept of SOE's social responsibility is the contribution to stakeholders, other than solely for the benefit of the company. Here the ultimate goal of SOE business activities is not only profit oriented, but also real attention and contribution to improving the quality of life of the surrounding community, in particular and the general public and the environment in general (Sumiyati, 2013). In general, the dissemination of Pancasila through the actualization of the Tri Hita Karana principle by SOE in relation to establishing harmonious relationships with humans is carried out through community awareness activities in the field of community social empowerment and community economic empowerment. In real terms, partnership and community development activities consist of providing loans to small businesses, education and/or training, improving health, providing public facilities and infrastructure. In the context of Pancasila Ideology, this is to realize the fifth principle of Pancasila, namely realizing social justice for all Indonesia people.

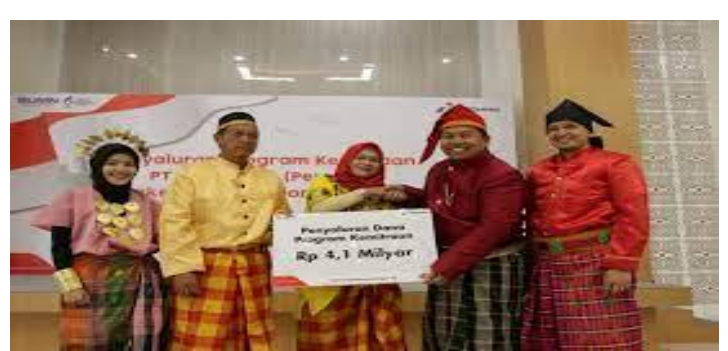

Figure 6 PT Pertama (Persero) Helps SMEs Upgrading by Providing Business Capital

\section{CONCLUSION}

Based on the discussion above, it can be concluded that the dissemination of Pancasila by SOE through the actualization of the Tri Hita Karana principle can be seen from the CSR and CSR of the company. SOE's efforts in disseminating Pancasila through the actualization of Tri Hita Karana can be observed in terms of establishing or building a harmonious relationship between companies and God Almighty, companies and the environment or nature, and companies and humans. Harmonious relationship between SOE and God Almighty carried out with SOE social activities whose orientation and direction is to support the community in religion or worship, for example building 
houses of worship, Ramadan package assistance, Eid al-Qurban assistance, Iftar with Orphans, Hajj assistance for Muslim employees, Tirtayatra for Hindu employees, Pilgrimage to Jerusalem for Christian employees and religious discussions, as well as spiritual development of employees. Harmonious relationship between SOE and the environment or nature. In an effort to disseminate Pancasila through the actualization of the principles of Tri Hita Karana, especially with regard to building a harmonious relationship with the environment, SOE has carried out investments in environmentally friendly sectors, maintaining a balance in the exploitation of natural resources, waste management (waste recycling), and other ways to maintain environmental balance and the like. Harmonious relationship between SOE and humans. In general, the dissemination of Pancasila through the actualization of the Tri Hita Karana principle by SOE in relation to establishing a harmonious relationship with humans is carried out through community awareness activities in the fields of community social empowerment and community economic empowerment, education or training, health improvement, implementation of public facilities and infrastructure

\section{REFERENCES}

[1] Ahsanulkhaq, M. (2019). Membentuk Karakter Religius Peserta Didik Melalui Metode Pembiasaan. Jurnal Prakarsa Paedagogia, 2(1), 21-33.
[2] Ardian. (2013). Faktor-faktor yang mempengaruhi kebijakan pengungkapan tanggung jawab sosial dan lingkungan.

[3] Aryawan, I. W. (2021). Application of Asta Brata Leadership in Education from the Point of View of Conflict Theory. Jurnal Ilmiah Ilmu Sosial, 7(1), 56-66. https://ejournal.undiksha.ac.id/index.php/JII S/article/view/31628

[4] Gumilar, S., Apsari, N. C., Raharjo, S. T., \& Wibhawa, B. (2019). Tanggung Jawab Sosial Perusahaan Dan Kesehatan Anak Balita (Kasus Pada Csr Pt. Pertamina Tbbm Bandung Group). Share: Social Work Journal, $8(2), \quad 225$. https://doi.org/10.24198/share.v8i2.19416

[5] Harahap, A. S. (2010). Pengaturan CSR Di Indonesia. Lex Jurnalica, 7, 182-190.

[6] Kapuy, H. R., Manajemen, P. S., Maroso, U. S., \& Belakang, A. L. (2018). Peran Relationship Quality Dalam Mengidentifikasi Functional Value Dan Satisfaction Terhadap Layanan CSR Bank BUMN Untuk Meningkatkan Loyalitas Mitra Binaan. 18(2), $1-8$.

[7] Kartika, I. M. (2015). Nilai-Nilai Pancasila Dalam Membangun Etika Politik Di Indonesia. Jurnal Kajian Pendidikan Widya Accarya FIKP Universitas Dwijwndra, 4(1). http://ejournal.undwi.ac.id/index.php/widyaa ccarya/article/view/444

[8] Kusumadewi, T. (2013). Kemitraan BUMN Dengan UMKM Sebagai Bentuk Corporate Social Responsibility (CSR) (Studi Kemitraan PT. TELKOM Kandatel Malang Dengan UMKM Olahan Apel Di Kota Batu). Jurnal Administrasi Publik Mahasiswa Universitas Brawijaya, 1(5), 953-961.

[9] Lestari, D. I. A. W. (2021). Rumah Sakit Islam Fatimah Cilacap.

[10] Purana, I. M. (2016). Pelaksanaan Tri Hita Karana Dalam Kehidupan Umat Hindu. Jurnal Kajian Pendidikan Widya Accarya FKIP Universitas Dwijendra, 2085, 67-76.

[11] Rakhmawati, D. (2011). UkuranPerusahaan, Perusahaan BUMN dan Non BUMN Terhadap Luas Pengungkapan Tanggung Jawab Sosial ( CSR DISCLOSURE ) pada 
Perusahaan di BEI Tahun SKRIPSI.

[12] Rauf. (2016). HAKIKATTANGGUNG JAWAB SOSIAL BUMN TERHADAP STAKEHOLDER Abdul Rauf Sekolah Tinggi Manajemen Informatika dan Komputer ( STMIK ) Dipanegara Makassar Dosen Hukum Perusahaan Email: a_rauf2002@yahoo.com dan hubungannya dengan institusi lain dalam masyarakat,. l(1).

[13] Rini, Wulan Setyo., Salim, M Agus., \& Priyono, A. A. (2021). Analisis Pengaruh Kinerja Keuangan Terhadap Tanggung Jawab Sosial Perusahaan (Corporate Social Responsibility) Pada Bank Bumn Di Indonesia (Studi Pada Bank Bumn Periode 2010-2019). Angewandte Chemie International Edition, 6(11), 951-952., 171180.

[14] Rita, R. (2019). Implementasi Corporate Social Responsibility. PUSAKA (Journal of Tourism, Hospitality, Travel and Business Event), 1(1), 29-35. https://doi.org/10.33649/pusaka.v1i1.10

[15] Santika, I. G. N., Kartika, I. M., \& Wahyuni, N. W. R. (2019). Pendidikan karakter: studi kasus peranan keluarga terhadap pembentukan karakter anak Ibu Sunah di Tanjung Benoa. Widya Accarya, 10(1).

[16] Santika, I. G. N. (2017). Kepala Sekolah Dalam Konsep Kepemimpinan Pendidikan: Suatu Kajian Teoritis. Widya Accarya, 7(1). http://103.39.12.42/index.php/widyaaccarya/ article/view/898

[17] Santika, I. G. N. (2018). Strategi Meningkatkan Kualitas SDM Masyarakat Desa Padangsambian Kaja Melalui Pendidikan Karakter Berbasiskan Kepedulian Lingkungan Untuk Membebaskannya Dari Bencana Banjir. Widya Accarya, 9(1).

[18] Santika, I. G. N. (2019). Presidensialisme Dan Problematika Mekanisme Impeachment Presiden Dan / Atau Wakil Presiden Berdasarkan UUD 1945 Pasca Perubahan ( Perspektif Pergulatan Hukum Dan Politik ). Jurnal Ilmiah Ilmu Sosial, 5(1), 23-34. http://dx.doi.org/10.23887/jiis.v5i1.18777

[19] Santika, I. G. N. (2020a). Menelisik Akar Kegaduhan Bangsa Indonesia Pasca
Disetujuinya Hasil Revisi UU KPK Dalam Perspektif Pancasila. Jurnal Ilmiah Ilmu Sosial, 6(1), 26-36. https://doi.org/10.23887/jiis.v6i1.25001

[20] Santika, I. G. N. (2020b). Menggali dan Menemukan Roh Pancasila Secara Kontekstual. Lakeisha.

[21] Santika, I. G. N. (2020c). Optimalisasi Peran Keluarga Dalam Menghadapi Persoalan Covid- 19: Sebuah Kajian Literatur. Jurnal Ilmiah Ilmu Sosial, 6(2), 127-137. https://doi.org/http://dx.doi.org/10.23887/jiis .v6i2.28437

[22] Santika, I. G. N. (2021a). Pendidikan Kewarganegaraan (Studi Komparatif Konstitusi Dengan UUD 1945). Lakeisha.

[23] Santika, I. G. N. (2021b). Tinjauan Historis Terhadap Keppres No. 24 Tahun 2016 Tentang Hari Lahir Pancasila. Vyavahara Duta, XVI(2), 5-24. https://doi.org/http://dx.doi.org/10.25078/vd. v16i2.2384

[24] Santika, I. G. N., Kartika, I. M., Ayu, I. G., \& Darwati, M. (2021). Reviewing The Handling Of Covid-19 In Indonesia In The Perspective Of The Pancasila Element Theory ( TEP ). Jurnal Etika Demokrasi (JED), 6(2), 40-51. https://doi.org/https://doi.org/10.26618/jed.v $6 \mathrm{i} 2.5272$

[25] Santika, I. G. N., Purnawijaya, I. P. E., \& Sujana, I. G. (2019). Membangun Kualitas Sistem Politik Demokrasi Indonesia Melalui Pemilu Dalam Perspektif Integrasi Bangsa Dengan Berorientasikan Roh Ideologi Pancasila. Seminar Nasional Hukum Dan Kewarganegaraan, $\quad 1(1), \quad 74-85$. https://eproceeding.undiksha.ac.id/index.php /semnashk/article/view/1665

[26] Santika, I. G. N., Rindawan, I. K., \& Sujana, I. G. (2018). Memperkuat Pancasila Melalui Pergub No. 79 Tahun 2018 Dalam Menanggulangi Pengikisan Budaya Di Era Revolusi Industri 4.0. Seminar Nasional Inovasi Dalam Penelitian Sains, Teknologi Dan Humaniora-InoBali, 79, 981-990.

[27] Saputra, P. B. A., Sutapa, I. N., \& Kurniawan, K. A. (2018). Akuntabilitas Pengelolaan Keuangan Desa Dalam Perspektif Budaya Tri Hita Karana. Jurnal Riset Akuntansi Dan 
Bisnis Airlangga, 3(1), 306-321. https://doi.org/10.31093/jraba.v3i1.90

[28] Sila, I. M., Purana, I. M., \& Awa, A. R. B. (2020). Penerapan Nilai-Nilai Pancasila Dalam Pelaksanaan Upacara Adat Purung Ta Kadonga Ratu Pada Masyarakat Desa Makatakeri Kecamatan Katikutana Kabupaten Sumba Tengah Provinsi Nusa TenggaraTimur (NTT). Widya Accarya, 11(1), 84-96.

[29] Sutrisno, N., Nyoman, N., Nikki, A., Sutarya, I. G., Duija, I. N., Surpi, N. K., Donder, I. K., Suwantana, I. G., Bagus, I., Surya, B., Pramana, A., Santika, I. G. N., \& Segara, I. N. Y. (2019). POLITIK HINDU. IHDN PRESS.

[30] Swarniti, N. W. (2019). The Translation Procedures of Bible Translation. RETORIKA: Jurnal Ilmu Bahasa, 5(2), 187-196. https://doi.org/10.22225/jr.5.2.1277.187-196

[31] Swarniti, N. W. (2021a). A Corpus Based Approach to the Analysis of Structures in Prepositional Phrase. Yavana Bhasha: Journal of English Language Education, 4(1), 18-22.

[32] Swarniti, N. W. (2021b). Translation Methods Found in New Testament Bible of Mark' s Gospel. RETORIKA: Jurnal Ilmu Bahasa, 7(2), 172-179. https://doi.org/https://doi.org/10.22225/jr.7.2 $.3823 .172-179$

[33] Swarniti, N. W. (2021c). The Analysis of Semantics Meaning Found In Comments of Instagram Account of Info Denpasar. Prosiding Seminar Nasional Linguistik Dan Sastra (SEMNALISA), 193-199. 